\title{
Effects of climate variability on breeding phenology and performance of tropical seabirds in the eastern Indian Ocean
}

\author{
Christopher A. Surman ${ }^{1, *}$, Lisa W. Nicholson' ${ }^{1}$, Jarrod A. Santora ${ }^{2}$ \\ ${ }^{1}$ Halfmoon Biosciences, Ocean Beach, Western Australia 6333, Australia \\ ${ }^{2}$ Farallon Institute for Advanced Ecosystem Research, PO Box 750756, Petaluma, California 94952, USA
}

\begin{abstract}
We compared 20 yr of seabird breeding data with oceanographic variables (sea level, sea-surface temperature) and a climate index (Southern Oscillation Index; SOI) for the lesser noddy Anous tenuirostris, brown noddy A. stolidus, sooty tern Onychoprion fuscata and wedgetailed shearwater Ardenna pacifica at the Houtman Abrolhos, eastern Indian Ocean. We found that timing of breeding and performance of these species is related to climate variability, mediated by oceanographic conditions within the eastern boundary Leeuwin Current (LC). The 3 migratory species have breeding parameters which are correlated with sea level and the SOI, while the first egg date of the resident lesser noddy is correlated with SST during their pre-breeding phase. There was poor breeding performance for each species during El Niño Southern Oscillation (ENSO) conditions; moreover, poor breeding success was recorded for all species outside of ENSO events in the latter years of the study. In addition, breeding was delayed for all species during the time of the present study. The environmental conditions contributing to this appear to be fewer years of strong LC flow with associated high sea levels, warmer SSTs, stronger eddy energy and increased productivity. Migratory seabird species breeding at this location appear less able to respond to climate variability - and its influence upon prey availability — than the resident species. It is suggested that the resident lesser noddy may have an advantage due to its response to a localised environmental cue, SST, in the pre-breeding phase, which may be correlated with prey availability in the waters surrounding the Houtman Abrolhos.
\end{abstract}

KEY WORDS: Seabirds · Indian Ocean - ENSO - Climate - Variability - Leeuwin Current · Demography $\cdot$ Lesser noddy

\section{INTRODUCTION}

A diversity of breeding strategies are demonstrated by seabirds to accommodate local trophic connections and ensure that reproductive success is maximized (Lack 1968). However, seabird breeding parameters (e.g. phenology, participation rates and breeding success) are often affected by large-scale atmospheric climate phenomena, such as the El Niño Southern Oscillation (ENSO; Dunlop et al. 2002, Ramos et al. 2006, Surman \& Nicholson 2009a,b) and the North Atlantic Oscillation (NAO; Frederiksen et al. 2004, Wanless et al. 2009), as well as localised weather con- ditions such as wind speed and sea-surface temperature (SST; Ramos et al. 2002, Smithers et al. 2003, Peck et al. 2004, Frederiksen et al. 2004, Jaquemet et al. 2007) that may limit the abilities of seabirds to adapt to changes in prey availability. Marine ecosystems are changing and are predicted to change substantially in response to climate change, with subsequent impacts to biodiversity and productivity (Poloczanska et al. 2007, Burrows et al. 2011). In particular, the timing of food availability is likely to shift in most marine environments, and seabirds will need to adjust their breeding phenology and/or trophic niche if they are to adapt to climate change. 
The ability to respond to climate variability, and variation in food availability (Ainley et al. 1995, Nicholson 2002, Surman \& Nicholson 2009a,b), appears to be influenced by life-history traits. Response to changing regional cues by seabirds in 2 North Sea colonies showed contrasting patterns, with the breeding phenology of some species becoming earlier, some not changing at all, and still others becoming later, which appeared to reflect differing life-history traits such as foraging method and diet (Wanless et al. 2009). Life-history traits such as a protracted post-natal growth period can inhibit such plasticity in timing of breeding in response to environmental cues, in which case other breeding parameters such as participation and success decrease in response to low food availability. For example, the wedge-tailed shearwater Ardenna pacifica (previously Puffinus pacificus), a highly synchronous migrant tropical seabird species with protracted post-natal growth, experiences high variation in breeding productivity at 4 colonies located between $20^{\circ}$ and $29^{\circ} \mathrm{S}$ in the eastern Indian Ocean, where poor years have been correlated with strong ENSO events, as measured by the Southern Oscillation Index (SOI; Dunlop et al. 2002, Nicholson 2002).

The degree to which a seabird can adjust their breeding phenology in response to climate variability may be dependent upon the environmental cues that they experience during their non-breeding phase. For example, migratory seabird species in the North Sea had an onset of breeding which was correlated with the NAO, whereas a resident species was more affected by localised SST (Frederiksen et al. 2004). Responding to more localised cues may confer some advantage for breeding success, as tropical seabird species breeding in the eastern Indian Ocean at $29^{\circ} \mathrm{S}$ experienced later onset of breeding and reduced productivity during seasons coinciding with ENSO events, although a resident species was less affected than the migratory species (Surman \& Nicholson 2009a,b).

In the eastern Indian Ocean, interannual variability of the ENSO cycle induces changes in the mesoscale variability (e.g. eddy shedding) of the poleward flowing Leeuwin Current (LC; Fig. 1) (Feng et al. 2009); the LC is the primary driver of marine ecosystem productivity along the Western Australian coastline. The LC is sourced from the Pacific via the Indonesian Through-Flow, and flows between latitudes $22^{\circ}$ and $34^{\circ} \mathrm{S}$ before turning eastwards and continuing into the Great Australian Bight. Seasonal and interannual variability of the LC is found to be a key factor influencing coastal SST, sea level, marine productivity and fisheries recruitments along the continental slope of the Western Australian coastline (Caputi et al. 2009, Feng et al. 2009, Thompson et al. 2011). This region is one of generally low biological productivity, as the low-density, warm waters of the LC flow southwards over the top of the cooler, denser, and northwardflowing Westralia Current, preventing upwellings of nutrient-rich waters into the photic zone (Feng et al. 2009). As a consequence, seabird abundance in the eastern Indian Ocean is much lower, and tropical species occur much further south, than at equivalent latitudes off the west coasts of Africa and South America, which possess northward-flowing currents and strong coastal upwellings (Wooller et al. 1991). The strength of flow of the LC and its eddy field varies seasonally, mostly due to variation of surface winds, as well as interannually (with the occurrence of ENSO events) in its cycle (Feng et al. 2009), with consequent effects upon marine pelagic production. During the austral winter and in La Niña (non-El Niño) years, the LC flow becomes more rapid, resulting in higher sea levels (by up to $20 \mathrm{~cm}$ at Fremantle; Feng et al. 2009) and warmer sea temperatures along shelf waters of the Western Australian coastline (Cresswell et al. 1989, Koslow et al. 2008, Thompson et al. 2011).

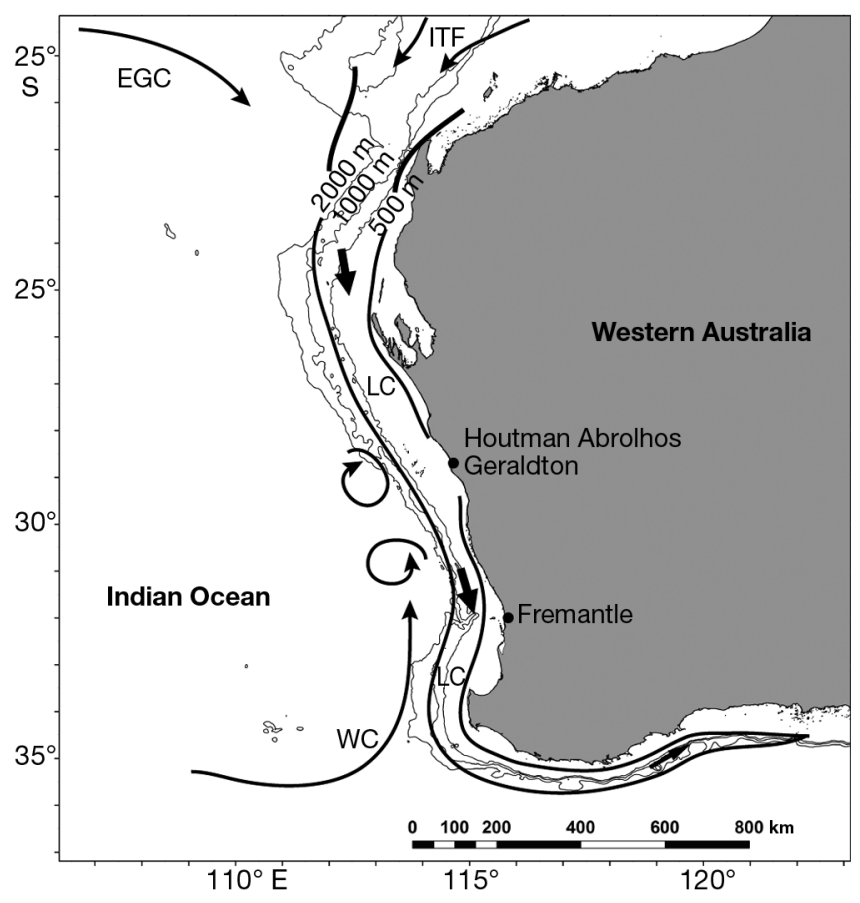

Fig. 1. Bathymetry of the Western Australian coastline, depicting the Indonesian Through-Flow (ITF), the Leeuwin Current (LC), the Eastern Gyral Current (EGC), the Westralia Current (WC) and the approximate positioning of the seasonal (autumn/winter) meso-scale eddies located near the Houtman Abrolhos 
Strong annual and seasonal differences in marine pelagic productivity associated with the biophysical properties in LC mesoscale eddies have been identified (Koslow et al. 2008, Feng et al. 2009), particularly north and south of the Houtman Abrolhos region $\left(29^{\circ} \mathrm{S}\right.$; Fig. 1). The Houtman Abrolhos is the central breeding area for the eastern Indian Ocean metapopulations of the lesser noddy Anous tenuirostris, brown noddy A. stolidus, sooty tern Onychoprion fuscata and wedge-tailed shearwater. This region contains one of the southernmost extensions of tropical marine flora and fauna in the Indian Ocean, principally due to the southward flow of the LC, which provides breeding seabirds with a mixture of tropical and temperate prey sources (Surman $\&$ Wooller 2003). In the present paper, we used $20 \mathrm{yr}$ of data (1991 to 2010) to compare seabird response to large-scale, regional and fine-scale climatic signals, as indicated by variation in the breeding parameters of these 4 species. As we are interested in the ability of seabirds to respond to variation in climatic signals, as determined by life-history traits, these are outlined for each of the study species in Table 1 and include non-breeding distribution, timing of breeding, foraging distance from breeding colony and breeding diet.

Previous studies found that breeding success was severely reduced in all 4 seabird species during ENSO events, which coincided with reduced vol- umes of key prey species in regurgitates, particularly in the noddy species (Surman \& Nicholson 2009a,b). Over time, increasing years of poor breeding performance for all species were recorded outside ENSO events, accompanied by a significant seasonal delay in the onset of breeding (date of first egg) in the 3 tern species (Surman \& Nicholson 2009a). Years of poor breeding performance were not restricted to the Houtman Abrolhos seabird colonies, as wedge-tailed shearwater colonies between $20^{\circ}$ and $29^{\circ} \mathrm{S}$ also had poor productivity in the same seasons (Dunlop et al. 2002), suggesting that these seabirds were all responding to the same large-scale environmental cue (ENSO variability). Therefore, our over-arching hypothesis is that timing of breeding and breeding performance by seabirds are related to climate variability, which is mediated by oceanographic conditions within the LC. Specifically, we predict that timing of breeding of the noddy and tern species (e.g. egg lay date) is frequently delayed in years characterized by lower sea levels, given that sea level is a proxy for the strength of the LC and that the LC flow is weaker during ENSO events. Furthermore, we postulate that a trend in later breeding dates of seabirds reflects changes in key prey resources (forage fish) that are governed by regional ocean conditions. To test this, we compared up to $20 \mathrm{yr}$ of seabird breeding parameters with oceanographic variables (sea level, SST) and a climate index (SOI).

Table 1. The non-breeding distribution, timing of breeding, foraging distance from the colony while breeding and breeding diet (collected between 1991 and 2001) for 4 species of seabirds breeding on Pelsaert Island at the Houtman Abrolhos, based on Gaughan et al. (2002), Surman \& Wooller (2003), Surman \& Nicholson (2009a)

\begin{tabular}{|c|c|c|c|c|}
\hline Species & Non-breeding distribution & $\begin{array}{l}\text { Timing of breeding } \\
\text { and mean lay date }\end{array}$ & $\begin{array}{l}\text { Foraging } \\
\text { distance }(\mathrm{km})\end{array}$ & Breeding diet \\
\hline $\begin{array}{l}\text { Sooty tern } \\
\text { Onychoprion } \\
\text { fuscata }\end{array}$ & $\begin{array}{l}\text { Dispersal from colony, } \\
\text { returning in late austral } \\
\text { winter/early spring }\end{array}$ & $\begin{array}{l}\text { Highly synchronous, } \\
\text { flexible timing, austral } \\
\text { spring in Oct-Nov }\end{array}$ & $480-600$ & $\begin{array}{l}\text { Wide variety of pelagic prey; } \\
>60 \% \text { squid, myctophids }\end{array}$ \\
\hline $\begin{array}{l}\text { Lesser noddy } \\
\text { Anous } \\
\text { tenuirostris }\end{array}$ & Over-winters at colony & $\begin{array}{l}\text { Synchronous, flexible } \\
\text { timing, austral spring } \\
\text { in Oct-Nov }\end{array}$ & 180 & $\begin{array}{l}\text { Larval ichthyoplankton, } \\
\text { several species; }>40 \% \\
\text { inshore larval beaked } \\
\text { salmon Gonorynchus greyi; } \\
27 \% \text { black-spotted goatfish } \\
\text { Parupenseus signatus }\end{array}$ \\
\hline $\begin{array}{l}\text { Brown noddy } \\
\text { Anous stolidus }\end{array}$ & $\begin{array}{l}\text { Dispersal from colony, } \\
\text { returning in late austral } \\
\text { winter/early spring }\end{array}$ & $\begin{array}{l}\text { Synchronous, flexible } \\
\text { timing, austral spring } \\
\text { in Oct-Nov }\end{array}$ & 180 & $\begin{array}{l}\text { Larval ichthyoplankton, } \\
\text { approximately } 70 \% \\
1 \text { species - inshore larval } \\
\text { beaked salmon } \\
\text { Gonorynchus greyi }\end{array}$ \\
\hline $\begin{array}{l}\text { Wedge-tailed } \\
\text { shearwater } \\
\text { Ardenna } \\
\text { pacifica }\end{array}$ & $\begin{array}{l}\text { Dispersal from colony, } \\
\text { returning in late austral } \\
\text { winter/early spring }\end{array}$ & $\begin{array}{l}\text { Highly synchronous, } \\
\text { static timing, } \\
\text { first egg } 17-23 \text { Nov } \\
\text { each year }\end{array}$ & Up to 400 & $\begin{array}{l}\text { Pelagic prey, few species; } \\
60 \% \text { squid, adult scaly } \\
\text { mackerel Sardinella lemuru }\end{array}$ \\
\hline
\end{tabular}




\section{MATERIALS AND METHODS}

\section{Study location and species}

The study was conducted on Pelsaert Island $\left(28^{\circ} 56^{\prime} \mathrm{S}, 113^{\circ} 58^{\prime} 30^{\prime \prime} \mathrm{E}\right)$, the southernmost and third largest of an archipelago of 192 islands, islets and rocks (the Houtman Abrolhos), $60 \mathrm{~km}$ off the midwestern coast of Australia (Fig. 1). Pelsaert Island (120 ha) is $12 \mathrm{~km}$ long, 50 to $500 \mathrm{~m}$ wide and very low ( $<3 \mathrm{~m}$ above high water), comprising sand and coral rubble on pavement limestone. On Pelsaert Island, the lesser noddy Anous tenuirostris (35000 pairs) nests in white mangrove Avicennia marina trees, the brown noddy Anous stolidus (130000 pairs) nests on low nitre bush Nitraria billardierei and samphire Halosarcia halocnemoides bushes, the sooty tern Onychoprion fuscata (260000 pairs) nests on bare ground below herbaceous Atriplex cinerea and nitre bushes and the wedge-tailed shearwater Ardenna pacifica (75000 pairs) digs burrows up to $1 \mathrm{~m}$ long in sandy areas throughout the southern portion of the island (Surman \& Wooller 1995, 2003). All 4 seabird species breed during the austral spring/summer (Table 1). The Pelsaert Island colonies contain 99\% of all brown noddies and $70 \%$ of all lesser noddies breeding along the Western Australian coastline, as well as the largest colonies of sooty terns and wedgetailed shearwaters in the eastern Indian Ocean. The tern species share breeding times of between 75 and 85 d (Surman 1998), while the wedge-tailed shearwater has a much longer breeding time of $120 \mathrm{~d}$ (Serventy et al. 1971) and, as a consequence, has the least ability to shift timing of breeding. The lesser noddy is a resident species at this location, with the other 3 species migrating northwards during the austral winter (Surman 1997). Differences in the diet of these 4 species are given in Table 1.

\section{Seasonal and interannual variability of the Leeuwin Current}

The LC is a unique southward-flowing tropical eastern boundary current of warm $\left(>24^{\circ} \mathrm{C}\right)$, lowsalinity $(<35 \%$ ) water which flows in a broad and shallow band (200 $\mathrm{km}$ wide by $50 \mathrm{~m}$ deep) at speeds of up to $2 \mathrm{~km} \mathrm{~h}^{-1}$, along the continental shelf of Western Australia (Cresswell 1990, Pearce 1991). For the purposes of analysing seabird response to climatic variation mediated by the $\mathrm{LC}$, we used the fine-scale climate signals of sea level at Geraldton and Fremantle (as Western Australian coastal sea level is a proxy for LC flow; Pearce 1991) and seasonal SST (austral winter, when LC flow is strongest, and austral spring, during the pre-breeding phase of the 4 study species) at the Houtman Abrolhos, as SST increases when LC flow is stronger (Feng et al. 2009).

\section{Breeding phenology, participation and success}

Nest sites of each species were selected at random and permanently marked. Nest contents were recorded weekly over the spring to summer period (September to May) between 1991 and 2001, and in more recent years (2002 and 2010), during several shorter visits between October and January of each year. There are some data gaps in these latter years which were excluded from analyses, and the resolution of breeding parameter data is higher for some of the study species, particularly in the latest $8 \mathrm{yr}$. The burrow contents of the wedge-tailed shearwater were determined using an electronic burrowscope (custom-made: model Nicholson 2010). Breeding participation was recorded as the percentage of the total sample size of nest sites or burrows that contained an egg, for each study species, during the breeding season. All 4 study species produce 1 egg clutch ${ }^{-1}$, and only the noddy and tern species are capable of re-laying if an egg is lost, predated, or damaged. Egglaying chronology was determined using lay dates of known age eggs, and the laying dates of other eggs were estimated by backdating, using egg-water loss techniques (Wooller \& Dunlop 1980, Surman \& Wooller 1995). Eggs known to be re-laid were excluded from calculations of the mean date of laying for each species. Chick age was estimated from growth curves described in Surman (1997).

\section{Environmental parameters}

Environmental data for the years 1991 to 2010 were used in all tests. ENSO events were measured using the SOI, which is based on the difference in atmospheric pressure between Tahiti, in the Pacific, and Darwin in northern Australia, and is expressed as positive values (La Niña) or negative values (El Niño) (Pearce \& Walker 1991). The mean monthly and total annual SOI was obtained from the Australian Bureau of Meteorology (www.bom.gov.au).

The strength of flow of the LC was proxied using the mean monthly sea level at Fremantle and Geraldton, Western Australia; data were obtained from the National Tidal Facility, Flinders University, Australia. 
Sea level height is a reliable indicator of the influence of the SOI upon the LC flow (Pearce 1991). Sea level is measured by remote tidal gauges in centimeters and presented in units of meters. Monthly mean SST $\left({ }^{\circ} \mathrm{C}\right)$ was obtained using the Reynold's SST database for the latitude band at $28.5^{\circ} \mathrm{S}$, between $113.5^{\circ}$ and $114.5^{\circ} \mathrm{E}$. For the purpose of comparison with breeding parameter data, SST was used for 2 pre-breeding periods (April to June and August to September). It was not the purpose of the present paper to look at potential effects of fine-scale fluctuations in SST during the breeding period for the 4 study species, but rather the oceanic conditions which may affect prey availability and distribution prior to breeding.

\section{Analysis}

Our first objective was to examine the relationship between ocean conditions and climate variability. To do this we used general linear regression to quantify the concordance among environmental variables within the LC. Our goal with this analysis was to describe the environmental state that seabirds experienced over a 20 yr period. Our second objective was to quantify and compare breeding parameters among seabird species to describe the patterns of breeding activity over the last $20 \mathrm{yr}$. It has previously been reported that the commencement of breeding was later between 2000 and 2007 when compared with 1991 to 1999 (Surman \& Nicholson 2009a). To test if tern species were breeding later and were being less successful through time, we used a general linear regression to compare the date of first egg, mean lay date, breeding participation and breeding success over time for the years 1991 to 2010, inclusive. Breeding success was used as a measure of reproductive performance, by estimating the proportion of all eggs laid that resulted in a fledgling. Trends over time were not corrected for changes in population size. Our third objective was to determine if there are environmental conditions that can be used to predict changes in seabird breeding phenology. To conduct this analysis, we first removed trends in seabird metrics and environmental variables (Hudson 2010) because we are interested in quantifying the covariation between seabirds and environmental conditions at the interannual scale. We used a combination of linear regression and nonparametric correlation analysis to compare seabird breeding metrics with environmental variables. Significance of correlation analysis was estimated using a Monte Carlo randomization ( $\mathrm{n}=5000)$ procedure (Manly 2007).

\section{RESULTS}

\section{Trends in timing of breeding, breeding participation and success}

Wedge-tailed shearwaters commenced breeding on or near 17 November each year, with no discernable interannual variability. Commencement of breeding was more variable for the noddy and tern species (Fig. 2), with first egg dates becoming significantly later through time (Table 2). In addition, the
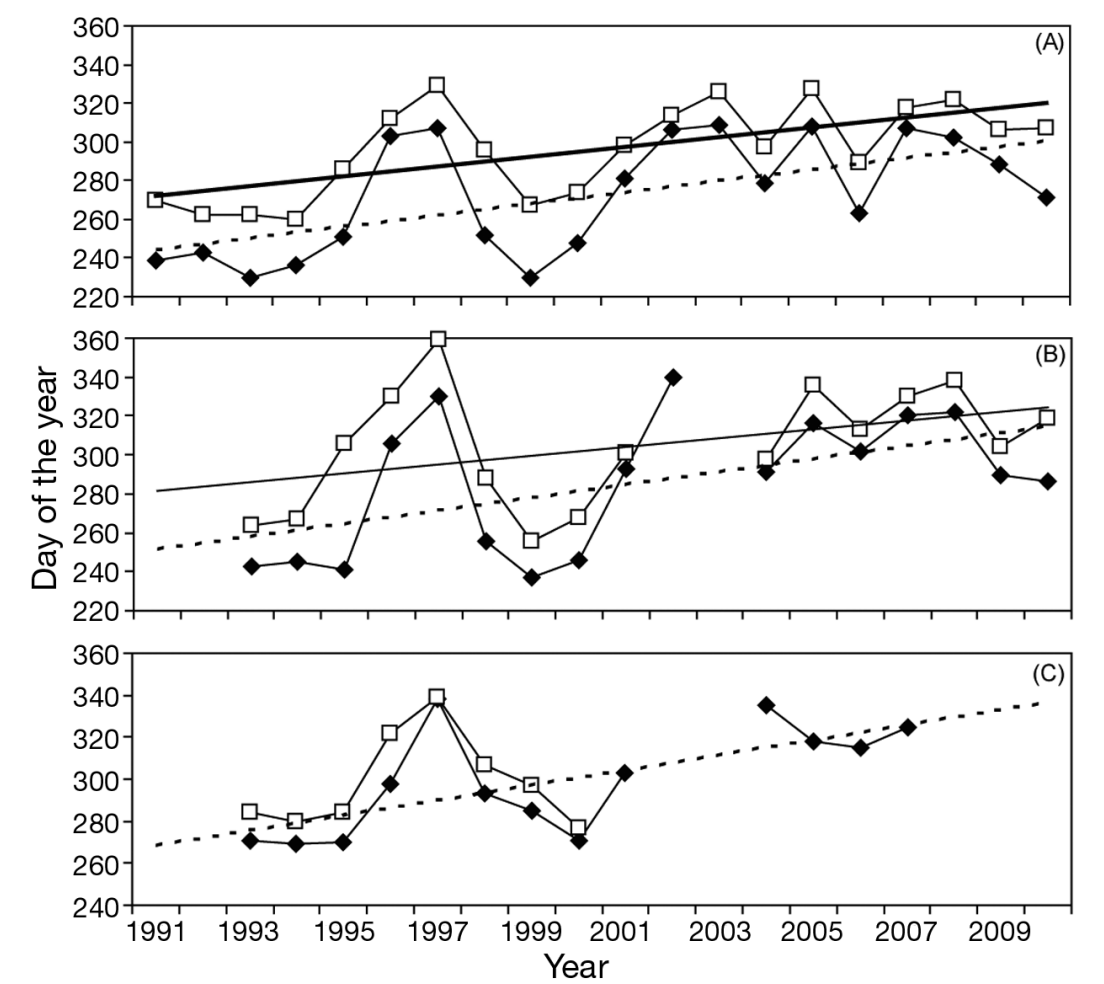

Fig. 2. Timing of breeding (day of the year, where 27 October $=300$ ) as represented by the date of first egg $(\diamond)$ and mean lay date ( $\square$ ) in (A) lesser noddy Anous tenuirostris, (B) brown noddy Anous stolidus and (C) sooty tern Onychoprion fuscata and wedge-tailed shearwater Ardenna pacifica (shown as a dashed line as there is no interannual variation within a $6 \mathrm{~d}$ period -17 to 23 November) at Pelsaert Island, Houtman Abrolhos, Western Australia, between 1991 and 2010. In (A, B) the dashed line indicates the trend for first egg and the solid line for mean egg dates, respectively 
Table 2. Trends over time (day of the year or percentage per year) for seabird breeding parameters from 1991 to 2010 for 4 species of seabirds breeding on Pelsaert Island, Houtman Abrolhos. Trends are uncorrected for changes in population size. An asterisk indicates insufficient data. Wedge-tailed shearwater egg dates not included as this species is highly synchronous and lays at the same time every year between 17 and 23 November. Bold values indicate significance at $\mathrm{p} \leq 0.05$

\begin{tabular}{|lccc|}
\hline Seabird breeding parameters & N (yr) & $t$ & $\mathrm{p}$ \\
\hline Lesser noddy Anous tenuirostris & & & \\
First egg date & 20 & 3.02 & $\mathbf{0 . 0 0 7}$ \\
Mean lay date & 20 & 3.45 & $\mathbf{0 . 0 0 3}$ \\
Participation & 19 & 0.29 & 0.78 \\
Success & 14 & -0.89 & 0.39 \\
Brown noddy Anous stolidus & & & \\
First egg date & 17 & 2.41 & $\mathbf{0 . 0 3}$ \\
Mean lay date & 16 & 1.73 & 0.10 \\
Participation & 17 & -0.02 & 0.98 \\
Success & 14 & 0.10 & 0.92 \\
Sooty tern Onychoprion fuscata & & & \\
First egg date & 13 & 3.03 & $\mathbf{0 . 0 1}$ \\
Mean lay date & 8 & 0.39 & 0.08 \\
Participation & 11 & 0.47 & 0.64 \\
Success & $*$ & $*$ & $*$ \\
Wedge-tailed shearwater Ardenna & pacifica & \\
Participation & 15 & -3.45 & $\mathbf{0 . 0 0 4}$ \\
Success & 10 & -2.29 & $\mathbf{0 . 0 5}$ \\
\hline
\end{tabular}

phenology of both noddy species was delayed significantly during the 1996-97 and 1997-98 austral summers, with mean lay dates 65 d later (lesser noddy) and 98 d later (brown noddy) than during preceding years (Fig. 2). Variability in the onset of breeding was greatest for brown noddies, with a range of $103 \mathrm{~d}$. In contrast, mean lay date for shearwaters varied by a single day each year (Fig. 2). While mean lay date became later for both noddy species, it was only significantly delayed for the lesser noddy (Table 2). Delays in breeding dates over time are also demonstrated by considering relative laying dates each year, measured as the difference between the longterm lay date (mean or first) and the annual mean date of laying (Fig. 3). There was a significant positive regression between the long-term mean date of first egg and the first egg date for each year between 1991 and 2010 in the lesser noddy $\left(t_{18}=3.03\right.$, $\left.\mathrm{p}=0.069, \mathrm{r}^{2}=0.34\right)$, brown noddy $\left(t_{15}=2.41, \mathrm{p}=\right.$ $\left.0.029, \mathrm{r}^{2}=0.28\right)$ and sooty tern $\left(t_{11}=3.03, \mathrm{p}=0.014, \mathrm{r}^{2}\right.$ $=0.46$ ) (Fig. 3). There was also a significant positive regression between the running long-term mean lay date and the mean lay date for each year between 1991 and 2010 in the lesser noddy $\left(t_{18}=3.45, \mathrm{p}=\right.$ $\left.0.003, r^{2}=0.39\right)$.
During 1991 to 2010, delayed breeding was accompanied by a decline in the proportion of the noddy and tern population participating per year (Fig. 4A). Wedge-tailed shearwater breeding participation declined significantly over time (Table 2). The lowest breeding participation was evident in 1996-97 for the sooty tern and lesser noddy (Fig. 4A). Wedge-tailed shearwaters, brown noddies and sooty terns did not attempt to breed during the 1997-98 ENSO event, and also showed low breeding participation during the 2002-03 ENSO event. The lesser noddy appeared to be the least affected during ENSO conditions, with breeding participation increasing during 1997-98 and 2002-03 compared with the previous seasons (Fig. 4A).

Breeding success data for all study species was not continuous after 2002. For the 2 noddy species, breeding success did not decline significantly over time (Table 2), but was low in the 1996-97, 1997-98, 2002-03 and 2004-05 seasons, coinciding with negative SOI values during these years (Fig. 4B). Poor breeding success occurred for all species outside probable ENSO events as well. Brown noddy breeding success was $<10 \%$ in 2007-08 (La Niña conditions) and in 2009-10, while lesser noddy breeding success was $>40$ and $30 \%$, respectively, in the same years. Wedge-tailed shearwater breeding success significantly declined over time (Table 2), and was zero for the 1997-98, 2007-08 and 2009-10 seasons (Fig. 4B).

\section{Relationships between climate signals}

As expected from the published literature, sea level at Geraldton and Fremantle was positively correlated with the SOI (Table 3, Fig. 5); higher sea levels were associated with positive SOI values reflective of La Niña conditions, while lower sea levels were associated with negative SOI values reflective of El Niño conditions. SST in the austral autumn of each year (when the LC becomes strongest in its annual cycle) was positively correlated with coastal sea levels in Geraldton and Fremantle, as well as with the SOI. The correlation between these signals was not significant within the late austral winter/early spring period (Table 3). The SST in the late austral winter/early spring was significantly and negatively correlated with SST in autumn so that higher SST in autumn was associated with lower SST in late winter/early spring, when the study species are present at the colony and preparing to breed. 


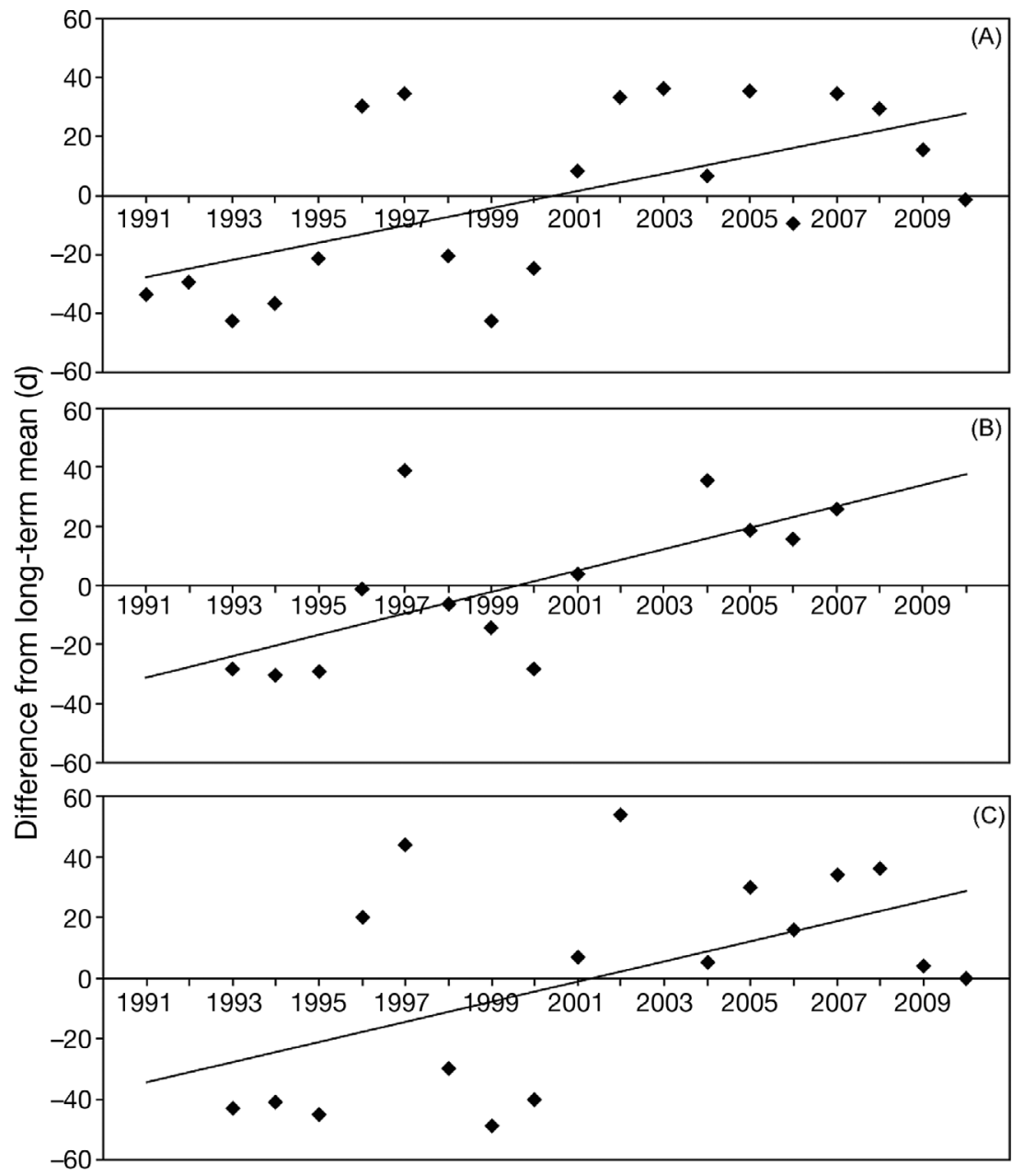

Fig. 3. Anous tenuirostris, Onychoprion fuscata, and Anous stolidus. Difference (in days) of the date of first egg from the long-term mean for the (A) lesser noddy, (B) sooty tern and (C) brown noddy at Pelsaert Island, Houtman Abrolhos, Western Australia, between 1991 and 2010

\section{Relationships between environmental variables and breeding seabirds}

We removed trends in order to examine the relationships among seabird breeding parameters and environmental variables. We found that first egg date of the brown noddy and sooty tern was inversely correlated to sea level at Geraldton (Table 4). First egg date of the lesser noddy was inversely correlated with SST during the pre-breeding months of August to September (Table 4); cooler SST in late winter/early spring results in later lay dates. Breeding success of the wedgetailed shearwater and brown noddy was significantly and positively correlated with sea level at Geraldton (and Fremantle for the wedge-tailed shearwater) and the SOI (Table 4), so that higher sea levels and SOI values resulted in more successful breeding seasons.

\section{DISCUSSION}

The timing of breeding and breeding performance of the seabirds at Houtman Abrolhos is related to climate variability, mediated by local oceanographic conditions within the LC off western Australia. Our first objective was to describe the environmental state that these eastern Indian Ocean seabirds have experienced over the past $20 \mathrm{yr}$. The relationships we found are as expected based on the literature (Pearce 1991, Feng et al. 2009). Local sea level was positively correlated with the SOI, with higher sea levels and autumn SSTs during positive periods of the SOI. When the SOI is positive, southward flow of the LC is stronger causing southward advection of warm subtropical waters from the Indonesian Flow-Through to the western Australian shelf (Cresswell et al. 1989, Koslow et al. 2008, Thompson et al. 2011). In turn, during years of positive SOI, greater LC flow, higher sea level and warmer SST, 2 of the migratory seabirds experienced earlier breeding, all 3 migratory species experienced increased breeding participation and higher breeding success. Similarly, for the resident lesser noddy, earlier onset of breeding was associated with warmer SST in late winter/early spring. It can therefore be concluded that positive SOI conditions (as observed during $\mathrm{La}$ Niña) are better for seabird breeding performance at the Houtman Abrolhos.

Mechanistically, the LC carries greater surface nitrate than surrounding waters. When the LC is active, marine productivity is enhanced, with extensive autumn/winter shelf-scale phytoplankton blooms and increased fisheries production (Caputi et al. 2009, Thompson et al. 2011). However, despite the fact that the LC advects warmer waters into the system, the bloom is maintained by cooling and storms (Koslow et al. 2008). There is also greater eddy energy associated with stronger flow of the LC, which increases vertical nutrient mixing and 

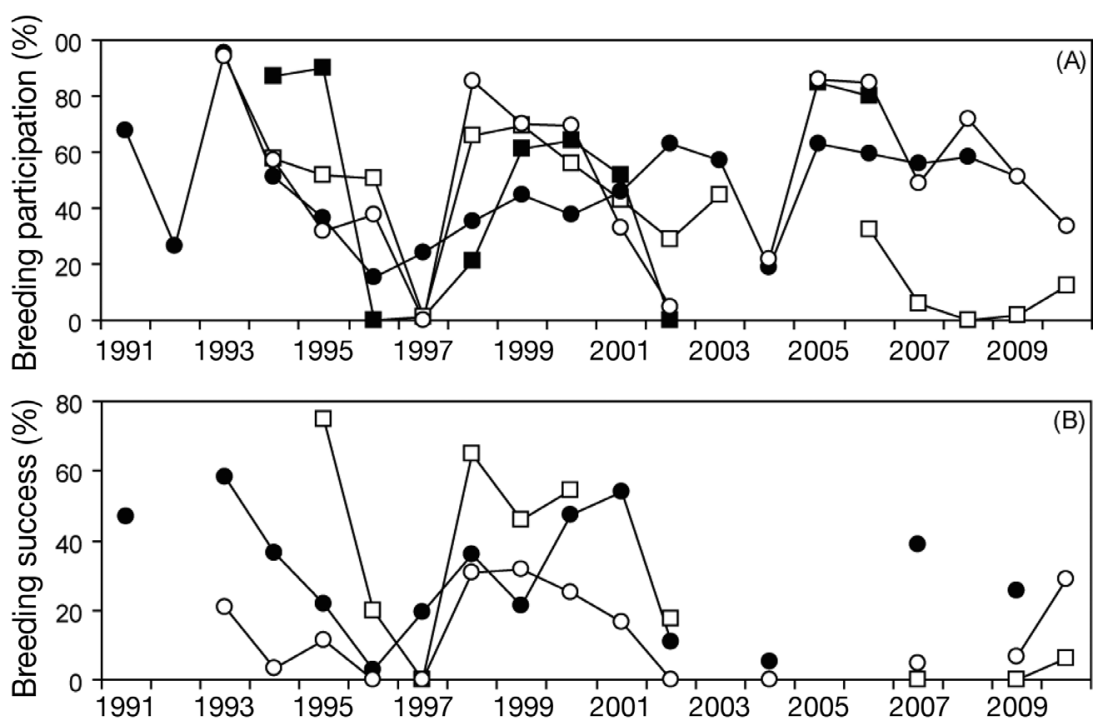

Fig. 4. (A) Breeding participation and (B) breeding success (both shown as percent) for the lesser noddy Anous tenuirostris (-), brown noddy Anous stolidus (O), sooty tern Onychoprion fuscata ( $\mathbf{\square}_{\text {; }}$ in Panel A only) and wedgetailed shearwater Ardenna pacifica ( $\square$ ) at Pelsaert Island, Houtman Abrolhos, Western Australia, between 1991 and 2010

Table 3. Spearman rank correlation among detrended environmental variables for 1991 to 2010. SOI: Southern Oscillation Index; SST: sea-surface temperature. Bold values indicate significance at $\mathrm{p}<0.05$

\begin{tabular}{|lcrrr|}
\hline & \multicolumn{2}{c}{ Sea level } & SOI & \multicolumn{1}{c|}{ SST } \\
& Geraldton & Fremantle & & (Aug-Sep) \\
\hline Sea level- & $\mathbf{0 . 9 2}$ & & & \\
Fremantle & & & & \\
SOI & $\mathbf{0 . 8 5}$ & $\mathbf{0 . 8 8}$ & & \\
SST (Aug-Sep) & 0.06 & -0.05 & -0.03 & \\
SST (Apr-Jun) & $\mathbf{0 . 5 4}$ & $\mathbf{0 . 5 2}$ & $\mathbf{0 . 5 2}$ & $\mathbf{- 0 . 4 5}$ \\
\hline
\end{tabular}

nutrient flux into the upper ocean and the transport of nutrients from shelf to pelagic waters (Moore et al. 2007, Feng et al. 2009). Enhanced production of zooplankton may result (Waite et al. 2007, Thompson et al. 2011). Some eddies within seabird foraging range of the Houtman Abrolhos have been observed to last for 5 mo (Moore et al. 2007), which would extend these conditions of higher productivity into the austral summer, during the study species' breeding season. In contrast, primary productivity and fisheries recruitment in the eastern Indian Ocean have been found to decline during ENSO conditions, when the LC flow is weaker and there is less eddy-energy (Koslow et al. 2008, Feng et al. 2009). This corresponds to our study in which breeding performance was reduced for all seabird species during ENSO.
Our second objective was to describe breeding activities for our 4 seabird species (Anous tenuirostris, A. stolidus, Onzchoprion fuscata and Ardenna pacifica) over the last $20 \mathrm{yr}$. Breeding participation and breeding success have been highly variable for each species as a result of the climate variability discussed above. However, we also found trends in the first egg dates (later) for the 2 noddy species and the sooty tern, as well as a longterm delay in the mean laying date for the lesser noddy. The species with the greatest variability in onset of breeding was the brown noddy. In addition to these trends in phenology, we found that breeding participation and breeding success of wedge-tailed shearwater declined over time. The association between sea level and lay date/ breeding success for the migratory species and between trending early spring SST and lay date for the resident lesser noddy suggests that lay date and breeding success for these species could be a proxy for a warming trend in SST, which is predicted to continue (Feng et al. 2004, Caputi et al. 2009).

Since the mid-1970s there have been more El Niño than La Niña events due to a climate regime shift in the Pacific Ocean (Feng et al. 2004), which has resulted in more years of a weak LC (and associated lower sea levels and lower SST) in recent decades (Caputi et al. 2009). The long-term increase in ENSO conditions may be a factor contributing to the significant negative changes in seabird parameters that we have recorded over a 20 yr period. Another contributing factor could be a $50 \mathrm{yr}$ warming trend, with later peak timing, in the austral autumn/winter SST off the lower west coast of Australia (Caputi et al. 2009). The SST has increased by 0.02 to $0.035^{\circ} \mathrm{C}^{-1}$, or an approximately $1{ }^{\circ} \mathrm{C}$ increase overall, while the spring to summer period shows little increase (Caputi et al. 2009). Over the $50 \mathrm{yr}$ period, the timing of the peak temperature has become delayed by 10 to $20 \mathrm{~d}$, which may also delay the processes influencing peak prey availability for spring/summer breeding seabirds. This delay could contribute to the significantly later first egg dates of the lesser noddy, given the significant correlation of this parameter with winter/spring SST.

Our third objective was to identify environmental conditions, or cues, that could be used to predict changes in seabird breeding phenology. The first egg 

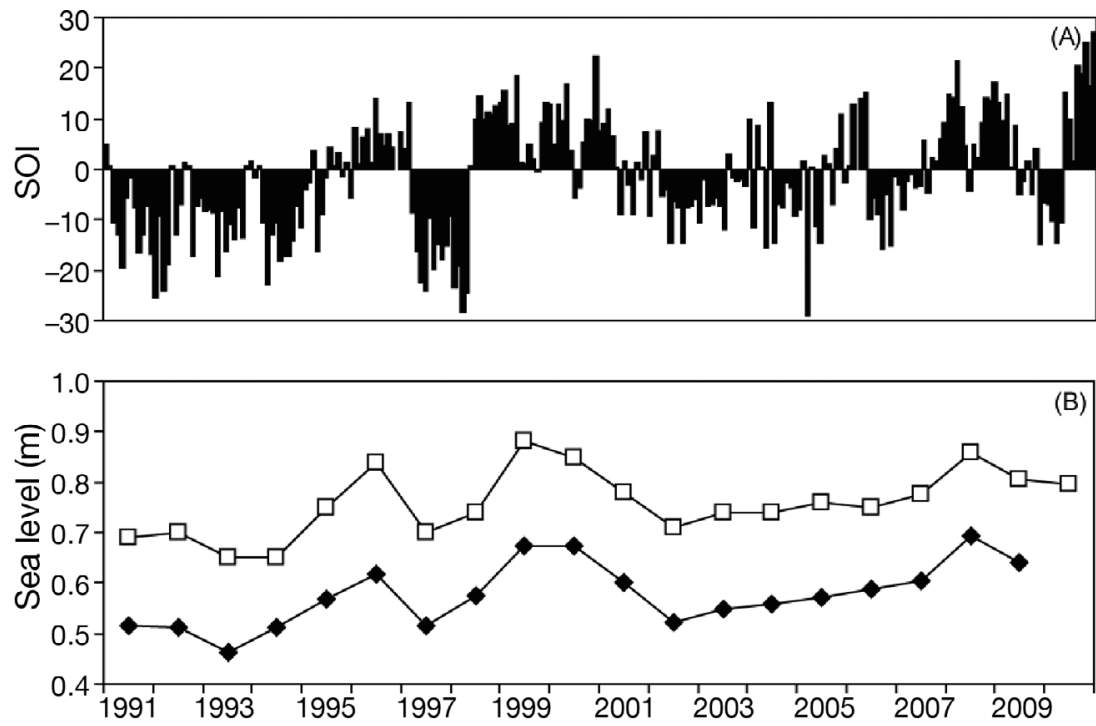

Fig. 5. (A) Southern Oscillation Index (SOI) and (B) sea levels at Geraldton $(\diamond)$ and Fremantle $(\square)$, Western Australia. El Niño Southern Oscillation events are associated with negative SOI values and lower sea levels

Table 4. Spearman rank correlations between detrended seabird breeding parameters and environmental variables from 1991 to 2010 for 4 species of seabirds breeding on Pelsaert Island, Houtman Abrolhos. SOI: Southern Oscillation Index; SST: sea-surface temperature. Bold values indicate statistical significance at $\mathrm{p}<0.05$

\begin{tabular}{|c|c|c|c|c|c|}
\hline \multirow{2}{*}{$\begin{array}{l}\text { Seabird breeding } \\
\text { parameters }\end{array}$} & \multicolumn{2}{|c|}{${ }_{-}$Sea level $\longleftarrow$} & \multirow[t]{2}{*}{ SOI } & \multicolumn{2}{|c|}{$-\mathrm{SST}$} \\
\hline & Geraldton & Fremantle & & Aug-Sep & Apr-Jun \\
\hline \multicolumn{6}{|c|}{ Lesser noddy Anous tenuirostris } \\
\hline First egg date & -0.28 & -0.05 & -0.12 & -0.72 & 0.30 \\
\hline Mean lay date & -0.24 & 0.00 & -0.09 & -0.34 & 0.18 \\
\hline Participation & -0.38 & -0.39 & -0.18 & -0.30 & 0.02 \\
\hline Success & 0.19 & 0.08 & 0.16 & -0.08 & -0.04 \\
\hline \multicolumn{6}{|c|}{ Brown noddy Anous stolidus } \\
\hline First egg date & -0.50 & -0.31 & -0.38 & -0.18 & -0.12 \\
\hline Mean lay date & -0.08 & 0.06 & -0.12 & -0.30 & -0.09 \\
\hline Participation & 0.24 & 0.07 & 0.24 & -0.01 & 0.22 \\
\hline Success & 0.47 & 0.44 & 0.54 & -0.11 & 0.35 \\
\hline \multicolumn{6}{|c|}{ Sooty tern Onychoprion fuscata } \\
\hline First egg date & -0.50 & -0.23 & -0.36 & -0.32 & -0.09 \\
\hline Mean lay date & -0.19 & 0.14 & -0.10 & -0.05 & -0.17 \\
\hline Participation & 0.35 & 0.04 & 0.14 & 0.03 & -0.21 \\
\hline \multicolumn{6}{|c|}{ Wedge-tailed shearwater Ardenna pacifica } \\
\hline Participation & 0.17 & 0.16 & 0.30 & 0.19 & 0.45 \\
\hline Success & 0.62 & 0.53 & 0.56 & 0.09 & 0.34 \\
\hline
\end{tabular}

date of the migratory brown noddy and the migratory sooty tern was significantly correlated with sea level at Geraldton $\left(29^{\circ} \mathrm{S}\right)$, with later laying associated with lower sea levels. The first egg date of the resident lesser noddy was significantly correlated with SST during the late austral winter/early spring, coinciding with the pre-breeding phase, with later laying associated with warmer SST. Breeding success of the wedge-tailed shearwater was significantly correlated with sea level at both Geraldton and Fremantle $\left(32^{\circ} \mathrm{S}\right)$, while, for the brown noddy, breeding success was significantly correlated with sea level at Geraldton, with poor breeding success associated with lower sea levels. Breeding success of both these species was also significantly related to the SOI, with poor years associated with negative $\mathrm{SOI}$ values.

Breeding phenology and success in tropical seabird colonies has frequently been linked to both localised and large-scale oceanographic events. In the western Indian Ocean, the colony productivity of roseate terns Sterna dougallii on Aride Island was related to intensity and timing of phytoplankton blooms during breeding (Monticelli et al. 2007), SST (Ramos et al. 2002) and the Multivariate El Niño Index (Ramos et al. 2002, Monticelli et al. 2007). ENSO events and severe La Niña years were found to have a strong influence upon brown noddies in the western Indian Ocean, where there was evidence of strong variation in food availability with poor breeding success (Ramos et al. 2006). Breeding phenology of sooty tern colonies coincided with a large monthly change in SST (an indicator of the annual phytoplankton bloom) just before the beginning of reproduction in the southwestern Indian Ocean (Jaquemet et al. 2007). Similarly, in the western Indian Ocean a roseate tern colony was found to be sensitive to inter-annual variations in the intensity and timing of a localised phytoplankton bloom (Monticelli et al. 2007). Breeding phenology and performance of tropical seabird species breeding in the eastern Indian Ocean (Dunlop et al. 2002, Surman \& Nicholson 2009a,b) and western Indian Ocean (Ramos et al. 2006) were influenced by the largescale oceanographic cues associated with ENSO events. At least 2 other studies of tropical seabird species, one at the Great Barrier Reef, north-eastern Australia, and the other in the Seychelles, western 
Indian Ocean, found that breeding success was influenced by both large-scale (ENSO) and localised (SST) oceanographic conditions (Ramos et al. 2002, Peck et al. 2004).

The data presented here suggest that the breeding parameters of our study species are decoupling from the strong negative influence of ENSO events reported previously (Surman 1998, Surman \& Nicholson 2009a), as there seems to be a cumulative effect of consecutive poor seasons upon breeding performance, and a reduction in the ability to have a successful season even when conditions appear favourable. It would appear that the environmental trigger for the arrival of prey for seabirds, perhaps as a result of a delayed autumn SST peak (Caputi et al. 2009), has shifted and has pushed seabirds to significantly later breeding. The resident lesser noddy was found to be the most resilient of the 4 species, as it adapted to later onset of breeding and was able to fledge chicks in the later years of our study when the other species had relatively poor breeding success. Local knowledge of the foraging grounds at the Houtman Abrolhos may be buffering the lesser noddy against variation in food availability to a greater extent than the other species, as the lesser noddy is able to switch prey in poor years so that it has rarely suffered complete breeding failure to the same extent as the brown noddy or sooty tern (Surman \& Nicholson 2009a). The correlation between first egg date and early spring SST for the lesser noddy suggests that this localised cue is indicative of food availability during the breeding season.

The effects of climate variability upon the LC and its eddy cycle in the past $20 \mathrm{yr}$ appear to have affected the availability of key seabird prey resources and seabird breeding cycles at the Houtman Abrolhos. As increased SST warming and increasing ENSO conditions are predicted to continue (Feng et al. 2004, Caputi et al. 2009), it is difficult to predict whether migratory seabirds can adapt to this variability in the long term and continue to successfully breed at the Houtman Abrolhos.

Acknowledgements. Many people have assisted in the field over the years, but we particularly thank R. and H. Surman, S. Oswald, A. Russell, B. Wise, M. Garkaklis, M. Nikulinsky, M.l Featherstone, N. Nicholson, J. Boreland and B. Fogg for their companionship in the field. We also thank our son Shae for his help, patience and enthusiasm. Transport was kindly provided by the crews of 'Phillip King', 'Le Chelle', 'Eco Abrolhos', 'Force Five', 'Southern Lady II', and 'ReefSeeker'. We are indebted to $M$. and W. McCrae, the Newton's, Basile's and Franceschi's of Burnett Island, as well as M. Davidson and P. Boschetti of Coronation Island for their support. We thank the Western Australian Department of Envi- ronment and Conservation (DEC) and the Department of Fisheries for permission to conduct research at the islands. M. Davidson, B. Humphries and J. Macfarlane of Chimera Pearls kindly provided accommodation. This research was in part funded by a Murdoch University Scholarship, the Fisheries Research and Development Corporation and the Natural Heritage Trust. From 2006 to 2008 funding was allocated through the DEC managed project 'Back from the Brink', with funding provided through the Northern Agricultural Catchments Council from State and Commonwealth funds. We also thank DEC's Geraldton Office for supporting the continuation of this research, particularly A. Desmond for his encouragement. We also thank J. N. Dunlop for his support over the years and his help as a fellow seabird botherer. Flinders University National Tidal Facility of Australia kindly provided sea level data, and A. Pearce of CSIRO, WA, kindly provided the Reynolds SST data. We also thank W. Sydeman for his encouragement and 4 anonymous reviewers whose input and comments greatly improved earlier drafts of this paper.

\section{LITERATURE CITED}

Ainley DG, Sydeman WJ, Norton J (1995) Upper trophic level predators indicate interannual negative and positive anomalies in the California Current food web. Mar Ecol Prog Ser 118:69-79

Burrows MT, Schoeman DS, Buckley LB, Moore P and others (2011) The pace of shifting climate in marine and terrestrial ecosystems. Science 334:652-655

Caputi N, de Lestang S, Feng M, Pearce A (2009) Seasonal variation in the long-term warming trend in water temperature off the Western Australian coast. Mar Freshw Res 60:129-139

Cresswell GR (1990) The Leeuwin Current. Corella 14: 113-118

Cresswell GR, Boland FM, Petersen JL, Wells GS (1989) Continental shelf currents near the Abrolhos Islands, Western Australia. Aust J Mar Freshwater Res 40:113-128

Dunlop JN, Long P, Stejskal I, Surman C (2002) Inter-annual variations in breeding participation at four Western Australian colonies of the wedge-tailed shearwater Puffinus pacificus. Mar Ornithol 30:13-18

Feng M, Li Y, Meyers G (2004) Multidecadal variations of Fremantle sea level: footprint of climate variability in the tropical Pacific. Geophys Res Lett 31:L16302. doi:10 1029/2004 GLO19947

Feng M, Waite AM, Thompson PA (2009) Climate variability and ocean production in the Leeuwin Current system off the west coast of Western Australia. J R Soc West Aust 92:67-81

> Frederiksen M, Harris MP, Daunt F, Rothery P, Wanless S (2004) Scale-dependent climate signals drive breeding phenology of three seabird species. Glob Change Biol 10:1214-1221

Gaughan D, Surman CA, Moran M, Burbidge A (2002) Feeding ecology of seabirds nesting at the Abrolhos Islands, Western Australia. Project 1998/203, Fisheries Research and Development Corporation, Perth

Hudson (2010) Interdisciplinary approaches towards new statistical methods for phenological studies. Clim Change 100:143-171

> Jaquemet S, Le Corre M, Quartley GD (2007) Ocean control of the breeding regime of the sooty tern in the southwest Indian Ocean. Deep-Sea Res 54:130-142 
Koslow JA, Pesant S, Feng M, Pearce A and others (2008) The effect of the Leeuwin Current on phytoplankton biomass and production off southwestern Australia. J Geophys Res 113:C07050. doi:10.1029/2007JC004102

Lack D (1968) Ecological adaptations for breeding in birds. Methuen Press, London

Manly BFJ (2007) Randomization, bootstrap, and Monte Carlo methods in biology, 3rd edn. Chapman and Hall, Boca Raton, FL

> Monticelli D, Ramos JA, Quartley GD (2007) Effects of annual changes in primary productivity and ocean indices on breeding performance of tropical roseate terns in the western Indian Ocean. Mar Ecol Prog Ser 351:273-286

Moore TS, Matear RJ, Marra J, Clementson L (2007) Phytoplankton variability off the Western Australian coast: mesoscale eddies and their role in cross-shelf exchange. Deep-Sea Res II 54:943-960

Nicholson LW (2002) Breeding strategies and community structure in an assemblage of tropical seabirds on the Lowendal Islands, Western Australia. PhD dissertation, Murdoch University, Perth

Pearce AF (1991) Eastern boundary currents of the southern hemisphere. J R Soc West Aust 74:35-45

Pearce AF, Walker DI (eds) (1991) The Leeuwin Current: an influence on the coastal climate and marine life of Western Australia. J R Soc West Aust 74:1-140

> Peck DR, Smithers BV, Krockenberger AK, Congdon BC (2004) Sea surface temperature constrains wedge-tailed shearwater foraging success within breeding seasons. Mar Ecol Prog Ser 281:259-266

Poloczanska ES, Babcock RC, Butler A, Hobday AJ and others (2007) Climate change and Australian marine life. Oceanogr Mar Biol Annu Rev 45:407-478

Ramos JA, Maul AM, Ayrton V, Bullock I and others (2002) Influence of local and large-scale weather events and timing of breeding on tropical roseate tern reproductive parameters. Mar Ecol Prog Ser 243:271-279

Ramos JA, Maul AM, Bowler J, Wood L and others (2006) Annual variation in laying date and breeding success of brown noddies on Aride Island, Seychelles. Emu 106: 81-86

Serventy DL, Serventy VN, Warham J (1971) The handbook of Australian sea-birds. Reed, Sydney

Smithers BV, Peck DR, Krockenberger AK, Congdon BC

Submitted: March 31, 2011; Accepted: March 20, 2012
(2003) Elevated sea surface temperature and reproductive failure of wedge-tailed shearwaters (Puffinus pacificus) in the southern Great Barrier Reef, Australia. Mar Freshw Res 54:973-977

Surman CA (1997) A comparative study of the breeding and feeding ecology of three sympatric tropical terns on the Houtman Abrolhos, Western Australia. PhD dissertation, Murdoch University, Perth, WA

Surman CA (1998) Seabird breeding schedules at the Pelsaert Group of islands, Houtman Abrolhos, Western Australia between 1993 and 1998. Rec West Aust Mus 19: 209-215

Surman CA, Nicholson LW (2009a) The good, the bad and the ugly: ENSO driven oceanographic variability and its influence on seabird diet and reproductive performance at the Houtman Abrolhos, eastern Indian Ocean. Mar Ornithol 37:129-138

Surman CA, Nicholson LW (2009b) El Niño Southern Oscillation and the Leeuwin Current influence on seabird reproductive performance and diet at the Houtman Abrolhos. J R Soc West Aust 92:155-163

> Surman CA, Wooller RD (1995) The breeding biology of the lesser noddy on Pelsaert Island, Western Australia. Emu 95:47-53

Surman CA, Wooller RD (2003) Comparative foraging ecology of sympatric terns at a sub-tropical, eastern-Indian Ocean island. J Zool (Lond) 259:219-230

> Thompson PA, Wild-Allen K, Lourey M, Rousseaux C, Waite AM, Feng M, Beckley LE (2011) Nutrients in an oligotrophic boundary current: evidence of a new role for the Leeuwin Current. Prog Oceanogr 91:345-359

Waite AM, Muhling BA, Holl CM, Beckley LE and others (2007) Food web structure in two counter-rotating eddies based on $\delta^{15}$ and $\delta^{13}$ isotopic analyses. Deep-Sea Res II 54:1055-1075

Wanless S, Frederiksen M, Walton J, Harris M (2009) Longterm changes in breeding phenology at two seabird colonies in the western North Sea. Ibis 151:274-285

Wooller RD, Dunlop JN (1980) The use of simple measurements to determine the age of silver gull eggs. Aust Wildl Res 7:113-115

Wooller RD, Dunlop JN, Klomp NI, Meathrel CE, Wienecke BC (1991) Seabird abundance, distribution and breeding patterns in relation to the Leeuwin Current. J R Soc West Aust 74:129-132

Proofs received from author(s): April 10, 2012 